\title{
Comparison of two types of proximal femoral hails in the treatment of intertrochanteric femur fractures
}

\author{
Gökçer Uzer, M.D., ${ }^{1}$ Nuh Mehmet Elmadağ, M.D.,, ${ }^{1}$ Fatih Yıldız, M.D., ${ }^{1}$ \\ Kerem Bilsel, M.D., ${ }^{1}$ Tunay Erden, M.D., ${ }^{1}$ Hüseyin Toprak, M.D. ${ }^{2}$ \\ ${ }^{1}$ Department of Orthopedics and Traumatology, Bezmialem Vakif University Faculty of Medicine, Istanbul \\ ${ }^{2}$ Department of Radiology, Bezmialem Vakif University Faculty of Medicine, Istanbul
}

\begin{abstract}
BACKGROUND: Hip nailing is frequently used to treat unstable intertrochanteric femoral fractures (ITF) in elderly patients. In this retrospective study, we compared the functional and radiological results, and the complications, of patients treated using proximal femoral nails (PFN) with an integrated, interlocking, compression lag screw, or two separate lag screws, which allow linear compression at the fracture site.

METHODS: A total of one hundred and eighteen patients were operated on for AO/OTA 3 I-A2 ITF between May 2010 and April 2012, and eighty-two of these patients, for whom sufficient follow-up data and documentation were available, were included into the study. PFNs with interlocking, integrated lag screws (Group I) were used in forty-four patients, and PFNs with two separate lag screws (Group II) in thirty-eight. Outcome parameters were the extent of varus collapse and leg length discrepancy on radiographs, and the Western Ontario and McMaster Universities Arthritis Index (WOMAC) and Harris hip scores (HHS) as functional results.

RESULTS: Mean follow-up duration was 20 months (range, 12-36 months); fractures healed in all patients. Mean varus collapse values were $2.03 \pm 5.68^{\circ}$ and $5.21 \pm 5.27^{\circ}(p=0.01)$, Harris hip scores $73.2 \pm 11.65$ and $74.72 \pm 11.15$ ( $\left.p=0.54\right)$, and WOMAC scores $70.78 \pm \mathrm{II} .4 \mathrm{I}$ and $7 \mathrm{I} .78 \pm \mathrm{II} .19(\mathrm{p}=0.69)$ in Groups I and II, respectively. No difference was detected between the groups in terms of outcome parameters or complication rate.
\end{abstract}

CONCLUSION: In the treatment of ITF, PFNs with an integrated, interlocking, compression lag screw, or two separate lag screws did not differ in terms of functional and radiological results or complication rate.

Keywords: Compression; hip nailing; intertrochanteric femur fractures; proximal femoral nail.

\section{INTRODUCTION}

Intertrochanteric femoral fractures (ITF) are one of the most frequent lower extremity fractures that usually occur following minor trauma in the elderly, caused by osteoporosis. [1,2] Hip nailing, which is associated with short surgery time, stable fixation, and early postoperative mobilization, is the preferred osteosynthetic method used to treat elderly patients with ITF. ${ }^{[3-12]}$

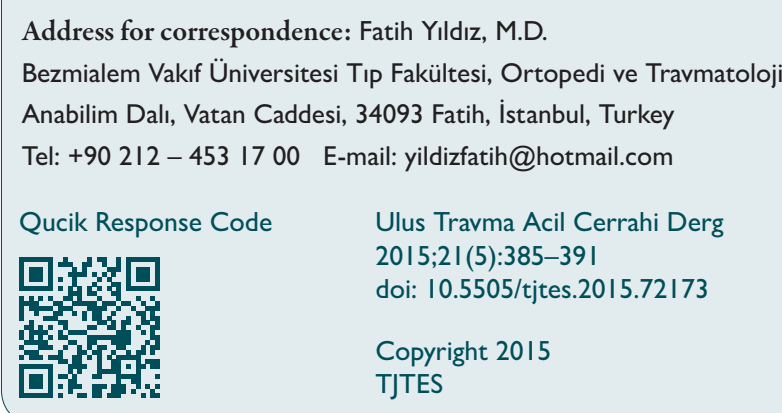

Several types and designs of proximal femoral nails (PFN) are in use; the PFN feature one or two lag screws; or integrated, interlocking lag screws or blades. Interfragmentary linear compression at the fracture site by the lag screws, which exerts important effects on bone healing, is possible with most hip nails. It was hypothesized that the treatment of ITF using a PFN with an integrated, interlocking lag screw would yield better outcomes and lower complication rates than the use of a PFN with two separate lag screws. The aim of this retrospective study was to compare two different hip nails in terms of functional and radiological results in patients treated via closed reduction and internal fixation using PFNs.

\section{MATERIALS AND METHODS}

A total of one hundred and eighteen consecutive patients diagnosed with ITF (AO 31-A2) was admitted to the Emergency Department of our hospital between May 2010 and April 2012, and were treated by six surgeons. This study was performed in accordance with the Declaration of Helsinki; 
data were collected from charts and the outcomes of the most recent postoperative follow-up visits.

\section{Inclusion and Exclusion Criteria}

Patients $\geq 60$ years of age at the time of surgery were included into the study. Patients who could not self-ambulate or who had severe neurological problems that affected ambulation were excluded. Trauma mechanism was another criterion; patients who developed ITF after a simple ground-level fall and who underwent at least 12 months of follow-up were included. Thirty-six patients were excluded; 17 were lost to follow-up, 16 died, and 3 underwent hemiarthroplasty because of metastatic lesions. Thus, eighty-two patients (48 female and 34 male; mean age, 76.6 years; range, $6 \mathrm{I}-\mathrm{II} 4$ years) were included. All patients were osteoporotic, with mean Singh's index values of $3.8 \pm 1.04$ and $4.1 \pm 1.19$ in Groups I and II, respectively $(p=0.207)$. Mean time to surgery after fracture was three days (range, I-I 3 days).

\section{Types and Designs of Proximal Femoral Nails}

PFNs with an interlocking, integrated lag screw (Group I) were used in forty-four patients (mean age, 76.I years; range, 67-89 years). PFNs with two separate lag screws (Group II) were used in thirty-eight patients (mean age, 78.5 years; range, 6I-II4 years). No difference in mean age was observed between the groups $(p=0.325)$. Intertan PFNs (Smith \& Nephew, Memphis, TN, USA), manufactured from a titanium alloy, with a trapezoidal cross-section, with a $4^{\circ}$ valgus offset, a $17 \mathrm{~mm}$ proximal-end diameter, a clothespin distal tip, and diameters of 10 and II $.5 \mathrm{~mm}$, were used in Group I. The lag and compression screws for Group I were an integrated, interlocking screw construct that included two screws of diameters of $\mathrm{II}$ and $7 \mathrm{~mm}$ (total, $15.5 \mathrm{~mm}$ ), and the nail was fixed via dynamic or static distal locking. The compression screw affords intraoperative interfragmentary compression at the fracture site. Profin PFNs (TST SAN, Istanbul, Turkey), cannulated straight tubes, are manufactured from titanium alloy, and have a proximal curvature of $6^{\circ}$ and a distal slotted design, and were used in Group II. Two 8.5-mm lag screws of neck-shaft angle $135^{\circ}$ were inserted. Interfragmentary fracture compression was also possible intraoperatively using this design. The proximal part of the nail was $16 \mathrm{~mm}$ in diameter, and the distal diameters of the nails were 10,11 , and $12 \mathrm{~mm}$. The nails also had two distal holes that allowed for dynamic or static fixation using $4.5-\mathrm{mm}$ locking screws.

\section{Surgical Technique}

All patients underwent surgery on a traction table in supine position. Closed reduction of the fracture was achieved under fluoroscopic control and minimally invasive techniques were used during nailing. Both nail types were inserted through the tip of the greater trochanter. Intraoperative interfragmentary compression was achieved in Group I after inserting an II mm lag screw using a $7 \mathrm{~mm}$ interlocking, integrated compression screw. However, interfragmentary compression was achieved in Group II using two separate lag screws inserted through the nail. The distal hole was statically locked in both groups.

\section{Follow-Up}

All patients were allowed to bear as much weight as they could tolerate on postoperative day I. The patients were examined at weeks 3 and 6, month 3, and after the first year; antero-posterior (AP) and lateral radiographs were taken.

\section{Outcome Parameters}

Maintenance of reduction, varus collapse, and union were the radiological outcomes evaluated by a radiologist. Fracture reduction was evaluated using the criteria of Baumgaertner et al., as modified by Fogagnolo et al. ${ }^{[13-16]}$ The collodiaphyseal angle was measured at the initial postoperative visit on follow-up AP radiographs. A collodiaphyseal angle that decreased to $<125^{\circ}$ during follow-up was considered to indicate significant varus collapse. Tip-apex distances (TAD) were measured as described by Baumgaertner, on the initial postoperative $\mathrm{X}$-rays of the patients who exhibited varus collapse (Fig. I). As two separate lag screws were used in Group II, TAD was measured from the tip of the proximal screw. ${ }^{[16]}$ Fracture union was defined radiologically as the development of callus, and, clinically, by a reduction in groin pain. WOMAC and $\mathrm{HHS}$ were evaluated as functional outcome. ${ }^{[17]}$

\section{Statistical Analysis}

Kolmogorov-Simirnov test was used to check for normality, Student's t-test to compare data between groups, and the chi-squared test to compare complication rates between the groups. P-values $<0.05$ were considered significant.

\section{RESULTS}

Seven patients (13\%) in Group I and nine (19\%) in Group

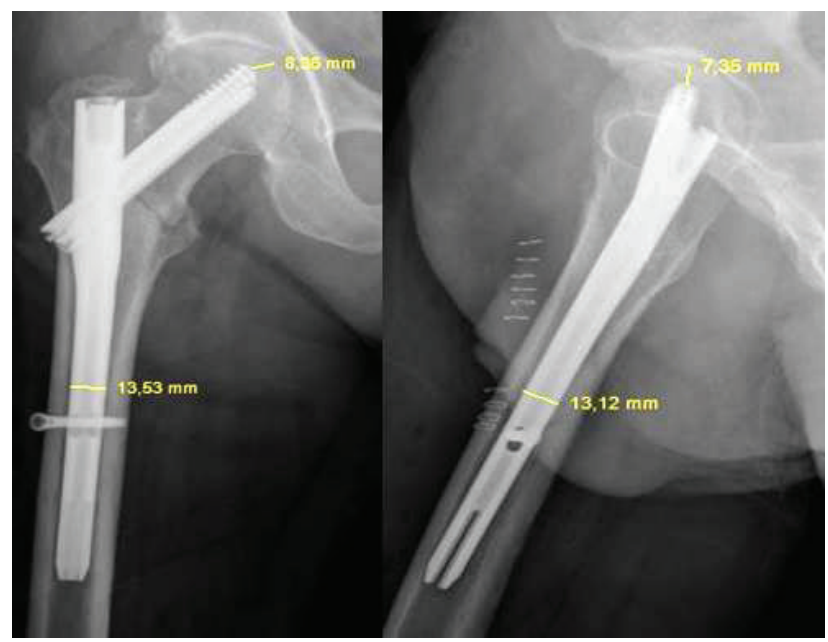

Figure 1. The tip-apex distance (TAD) is the sum of the distances from the tip of the lag screw to the apex of the femoral head on both the AP and lateral X-Rays. Measurement of corrected TAD of a patient is illustrated ( $T A D=8.36 \times \frac{13}{13.53}+7.35 \times \frac{13}{13.53}=15.3 \mathrm{~mm}$ ). 
Table I. Patient demographics and results

\begin{tabular}{lccr}
\hline & Group I & Group 2 & p \\
\hline Gender & & & \\
$\quad$ Male & $17(38.6 \%)$ & $17(44.7 \%)$ & 0.576 \\
$\quad$ Female & $27(61.4 \%)$ & $21(55.3 \%)$ & $<0.05$ \\
Age & $76.1(61-89)$ & $78.5(64-114)$ & $=0.55$ \\
HHS & $73.2 \pm 11.65$ & $74.72 \pm 11.15$ & $=0.69$ \\
WOMAC & $70.78 \pm 11.41$ & $71.78 \pm 11.19$ & $=0.01$ \\
The difference in collodiaphyseal angle & 2.37 & 6.098 & $=0.20$ \\
Singh index & 3.82 & 4.13 & $=0.37$ \\
Complication rate & $16 \%(7)$ & $24 \%(9)$ & \\
\hline
\end{tabular}

HHS: Harris Hip Score; WOMAC: Western Ontario and McMaster Universities Arthritis Index.

II died during follow up. The remaining forty-four patients in Group I and thirty-eight in Group II attained their final follow-ups. Mean follow-up duration was 20 months (range, 12-36 months).

According to the criteria of Baumgaertner et al., as modified by Fogagnolo et al., the quality of reduction was good in eighteen patients, acceptable in nineteen, and poor in seven of Group I; and good in sixteen, acceptable in fourteen, and poor in eight of Group II.

Mean initial postoperative and final follow-up neck-shaft angles were $|30.4| \pm 5.30^{\circ}$ and I $28.38 \pm 7.37^{\circ}$ in Group I $(p=0.02)$ and $|3| .76 \pm 4.83^{\circ}$ and $126.54 \pm 6.12^{\circ}$ in Group II $(p<0.00$ I). Mean initial postoperative $(p=0.235)$ and final follow-up neck-shaft angles $(p=0.229)$ were similar between the groups. Significant varus collapse was observed in seven patients in each group. Mean extent of significant varus collapse was $2.03 \pm 5.68^{\circ}$ in Group I and $5.21 \pm 5.27^{\circ}$ in Group II ( $p=0.0$ I; Table I). Mean TAD values on the initial postoperative $X$-rays of patients with varus collapse were $34.10 \pm 9.85$ and $32.07 \pm 11.37$ in Groups I and II, respectively $(p=0.74)$.

Mean HHS and WOMAC scores were $73.2 \pm 11.65$ and $70.78 \pm 11.41$ in Group I and 74.72 \pm 11.15 and $71.78 \pm 11.19$ in

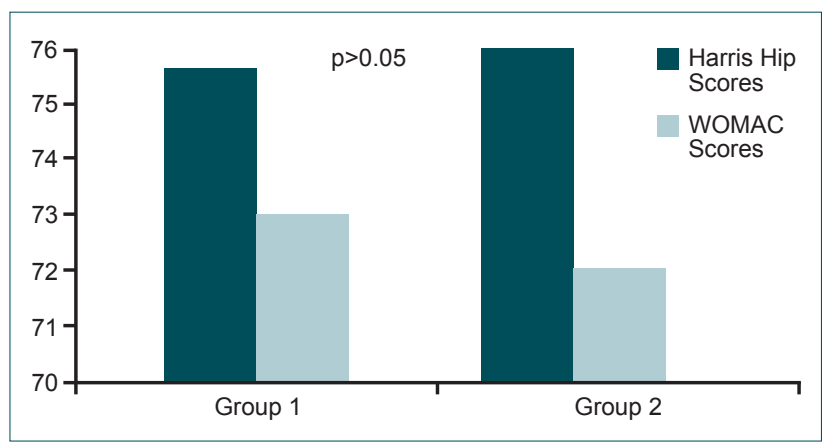

Figure 2. No significant difference in mean HHS or WOMAC score was evident between Groups I and II.
Group II, respectively. The differences in mean HHS $(p=0.549)$ and WOMAC scores $(p=0.690)$ were not significant between the groups (Fig. 2).

\section{Complications}

Seven complications occurred in seven patients in Group I because of significant varus collapse: lateral migration of lag screws in four, lag screw cut-out in two (the screws were replaced with shorter screws), and chondral destruction because of a malpositioned lag screw in one (who later underwent total hip arthroplasty) (Fig. 3a-c). Nine patients in Group II developed nine complications: two superficial infections treated via appropriate medications, two iatrogenic femoral shaft fractures revised using long recon nails, and seven with significant varus collapse. Superior malpositioning of the lag screws in one patient who had varus collapse was revised with use of a long recon nail. Hypertrophic nonunion in one patient was revised using a $95^{\circ} \mathrm{AO}$ plate and an autograft.

The Z-effect was evident in four patients after varus collapse; two were asymptomatic after removing the screws; and the other two did not undergo any intervention. A lag screw in one patient was revised due to a reverse Z-effect (Fig. 4a-d). The complication rates in Groups I (16\%) and II (23\%) did not differ $(p=0.37)$ (Tables 2 and 3).

\section{DISCUSSION}

Stable fixation and early mobilization decrease both morbidity and mortality rates and improve functional results when ITF is to be treated in elderly patients and those with osteoporosis. ${ }^{[3,4]}$ Most complications associated with PFN use while treating ITF are varus collapse of the proximal femur, cut-out, shortening of the femur, non-union, secondary fracture of the femur or trochanter major, thigh pain, screw fracture, heterotopic ossification, and a Z-effect or reverse Z-effect of nails with two lag screws. ${ }^{[4]}$ In this study, two different PFNs 

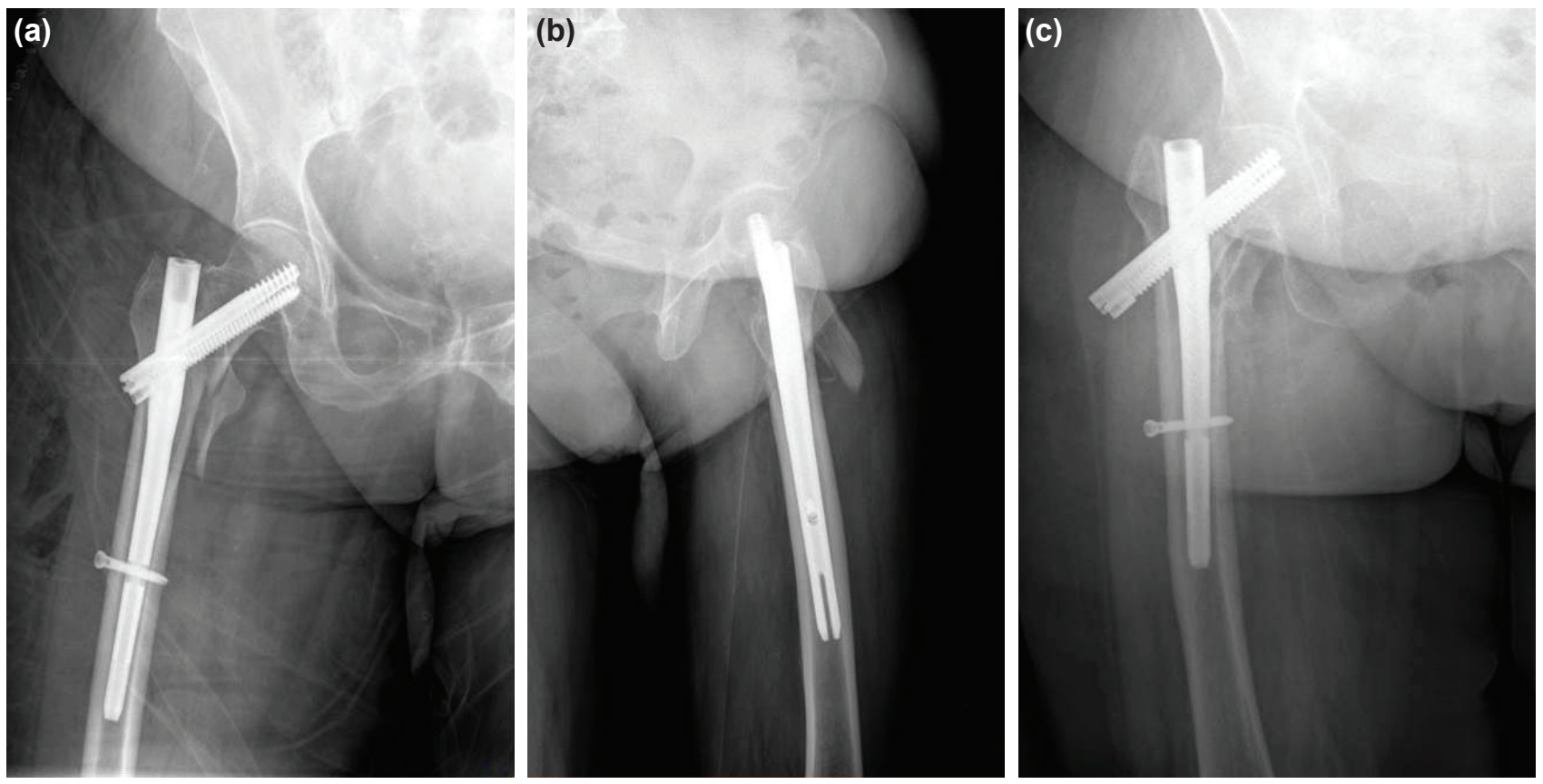

Figure 3. (a) Early postoperative antero-posterior X-ray of a patient in Group I. (b) Early postoperative lateral X-ray of the patient. (c) Lateral migration of the lag screw construct and varus collapse.

were compared, which are used in the treatment of unstable ITFs, and it was found that two different PFN designs yielded comparable results. Although the collodiaphyseal angle decreased significantly in both groups during follow-up, the extent of varus collapse was significantly higher in Group II than in Group I. Despite the statistically significant extent of varus collapse in both groups, neither the functional results nor the union and complication rates differed between the groups.

In our study, the significant varus collapse was most probably caused by an increased TAD, evident on the initial postoperative X-rays (34.10 19.85 and $32.07 \pm 11.37$ in groups I and II, respectively). Lag screw design, which allows for intraopera- tive linear compression of the fracture, may explain why fewer cases of varus collapse were evident in group I than group II. However, the varus collapse rate did not directly correlate with union rate. Ruecker et al. have evaluated the outcomes of patients fixed with Intertan PFNs to treat ITF and reported varus collapse in two of 48 patients, although both had TAD values $<5 \mathrm{~mm}$ on AP radiographs. ${ }^{[18]}$ In the study of Zhang et al., InterTAN and proximal femoral nail antirotation (PFNA) have been compared. The results have shown that the extent of shortening at the femoral neck is greater in the InterTAN than in the PFNA group, whereas all of the union rate, walking ability, Harris hip score, and hip range of motion, have been similar between the two groups. ${ }^{[19]}$
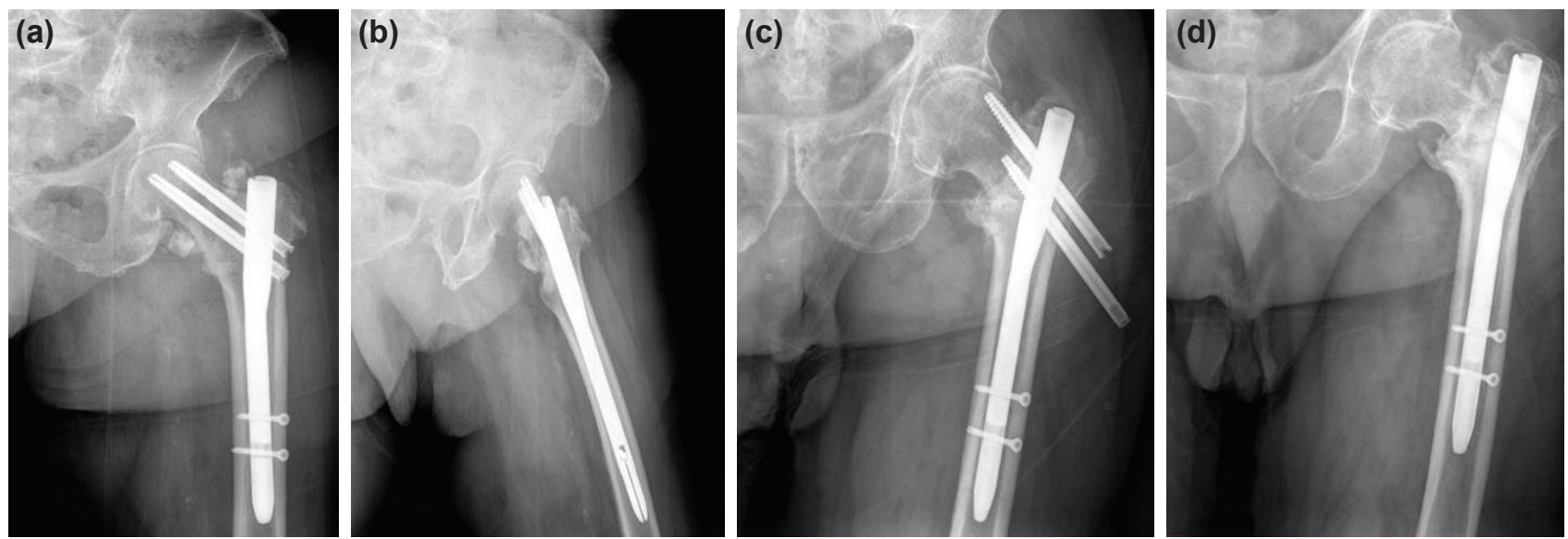

Figure 4. (a) Early postoperative antero-posterior X-ray of a patient in Group II shows acceptable fracture reduction and fixation using hip nailing with two separate lag screws. (b) The lateral X-ray shows an acceptable reduction, and that the screws are in the proper positions. (c) The Z-effect in a group II patient as evident in a radiograph taken 6 months postoperatively. (d) Lateral migration of an inferior lag screw caused irritation and pain in the trochanteric area because of the Z-effect, which was treated by removing the screws after fracture union. 
Table 2. Patient complications

\begin{tabular}{lcc}
\hline Complications & Group I & Group 2 \\
\hline Hypertrophic nonunion & - & I \\
Secondary fracture & - & 2 \\
Z effect & - & 4 \\
Reverse Z effect & - & I \\
Superficial infection & - & 2 \\
Lateral migration & 4 & - \\
Cut-out & 2 & - \\
Chondral destruction & I & - \\
\hline
\end{tabular}

The results of a biomechanical study comparing PFNs with one or two lag screws have indicated that PFNs with two lag screws might be a better option in patients with good bone quality, but have been associated with a higher risk of cutout in elderly patients with osteoporosis. ${ }^{[20]}$ In our study, the cut-out rate as a result of varus collapse was $4.5 \%$ in Group I, consistent with studies by Ruecker et al. (4.I\%) and Megas et al. (4.6\%). ${ }^{[2]}$ Zhang et al. have reported a cut-out rate of $\mathrm{I}-3 \%$ in a PFNA group, whereas no patient has developed cut-out in the Intertan group. ${ }^{[19]}$ In the biomechanical study of Huang et al., femoral strength, stability, and bearing capacity have been higher in the InterTAN group than in the PFNA group. ${ }^{[22]}$

Lin has reported that the use of PFNs with two lag screws is effective to treat AO OTA AI-A2-A3 ITF ${ }^{[17]}$ In the study by Erturer et al., union has been achieved in all thirty-two patients treated using Profin PFNs, although two patients have undergone revision surgeries because of poor fracture reduction. ${ }^{[23]}$

Gardenbroek et al. have retrospectively reviewed one hundred and fifty-seven patients with unstable ITF; the patients have been treated using PFNA or PFNs. The results were similar when the position of the implant in the femoral head was compared between nail types, but the risk of complications and the need for secondary surgery were higher in the PFN group than in the PFNA group. ${ }^{[5]}$ In our study, the risks of secondary surgery and screw cut-out did not differ between the groups.

The Z-effect (lateral migration of an inferior lag screw), varus collapse, perforation of the femoral head by the superior lag screw, the "reverse Z-effect," (lateral migration of a superior lag screw), and medial migration of the inferior lag screw, typically occur because the proximal fragment tilts as a result of insufficient medial cortical support. ${ }^{[24,25]}$ WernerTutschku et al. first defined the Z-effect and reverse Z-effect in five of 70 patients, and the cut-out rate was $8.6 \%$. They recommended fracture fixation at a neck-shaft angle $>125^{\circ}$ to decrease the risks of the Z-effect, reverse Z-effect, and screw cut-out of the femoral head. ${ }^{[26]}$ Papasimos et al. have reported the $Z$ effect in four of 40 patients. ${ }^{[3]}$ The reverse $Z$ effect has been seen in five of 35 patients in the series of Uzun et al. ${ }^{[4]}$ and in two of 55 patients in the study by Boldin et al. ${ }^{[4,27]}$ In a study by Herrera et al., including two hundred and fifty patients treated for pertrochanteric femoral fractures using the Gamma Nail and PFNs, the rates of cut-out and fracture around nail tips have been statistically significantly higher in the Gamma Nail group than in the PFN group, but the rates of varus collapse and lag screw migration have been significantly higher in the PFN group than in the Gamma Nail group. ${ }^{[28]}$ In our study, the neck-shaft angle was $<125^{\circ}$ in seven patients of Group I, and lateral migration was detected in four; they did not undergo re operations, but the proximal lag screws were replaced with shorter screws in two patients because of screw cut-out. Nine Group II patients had collodiaphyseal angles $<125^{\circ}$, and varus collapse and the Z-effect were observed in four; the lag screws were removed in two patients. The lag screw of one patient in Group II was replaced with a shorter screw because a reverse Z-effect was evident.

Table 3. Comparison and review of the complication rates of our study and those in the literature.

\begin{tabular}{|c|c|c|c|c|c|}
\hline & Patient $(n=)$ & $\begin{array}{c}\text { Complication rate } \\
(\%)\end{array}$ & $\begin{array}{l}\text { Cut-out } \\
(\%)\end{array}$ & $\begin{array}{c}\text { Lateral migration*I } \\
\text { Z-Effect }{ }^{* *}\end{array}$ & $\begin{array}{c}\text { Death rate } \\
(\%)\end{array}$ \\
\hline \multirow[t]{2}{*}{ Herrera et al. ${ }^{[25]}$} & $125_{(\mathrm{PFN})}$ & 4.8 & 0.8 & $3.2^{* *}$ & 29 \\
\hline & $125_{(\text {Gamma Nail) }}$ & 7.2 & 4 & $5.6^{*}$ & 24 \\
\hline Park et al. ${ }^{[28]}$ & 46 & 10.8 & - & $4.3^{* *}$ & 8.6 \\
\hline Soucanye de Landevoisin et al. ${ }^{[29]}$ & 102 & 16.7 & 2.9 & $15.7^{*}$ & 28 \\
\hline Werner-Tutschku et al. ${ }^{[23]}$ & 70 & 10 & 8.5 & $7.1^{* *}$ & 1.4 \\
\hline Simmermacher et al. ${ }^{[7]}$ & 315 & 14.6 & 1.2 & 0.6 & 16.8 \\
\hline \multirow[t]{2}{*}{ Current study } & $44_{\text {(Intertan) }}$ & 16 & 4.5 & $9.1^{*}$ & 13.4 \\
\hline & $38_{(\text {Profin) }}$ & 23 & - & $13^{* *}$ & 19.5 \\
\hline
\end{tabular}

\footnotetext{
*: Lateral migration of the lag screws; **: Lateral migration of the inferior lag screw and cut-out of the superior lag screw due to varus collapse of the femoral head.
} 
A secondary fracture distal to the nail is a significant complication of hip nailing. Banan has reported this complication in two of 46 patients and Fogagnolo et al. in one of 47.[14,29] Similarly, two of our Group I patients exhibited this complication; one was revised immediately, and the other three days later, using long femoral antegrade nails. This complication did not occur in any Group II patients.

In a study by Rappold et al., nail fractures around the proximal screw holes have occurred in three patients. ${ }^{[30]}$ In our study, we achieved union using a $95^{\circ} \mathrm{AO}$ plate after lag screw fractures developed in one patient.

\section{Limitations}

We investigated the effect of lag screw design on outcome. The Barthel index and the Parker and Palmer mobility score are other appropriate measures of functional outcomes but we did not use them in the current study. The retrospective study design and the small number of patients constitute other limitations.

\section{Conclusion}

Hip nailing is a safe and minimally invasive method for the treatment of unstable intertrochanteric femoral fractures. Our functional and radiological results, and complication rates, did not differ significantly when a PFN with an integrated, interlocking, lag screw construct, or a PFN with two separate lag screws, were used.

\section{Conflict of interest: None declared.}

\section{REFERENCES}

1. Bjørgul K, Reikerås O. Incidence of hip fracture in southeastern Norway: a study of 1,730 cervical and trochanteric fractures. Int Orthop 2007;31:665-9. CrossRef

2. Finsen V, Johnsen LG, Tranø G, Hansen B, Sneve KS. Hip fracture incidence in central norway: a followup study. Clin Orthop Relat Res 2004;419:173-8. CrossRef

3. Papasimos S, Koutsojannis CM, Panagopoulos A, Megas P, Lambiris E. A randomised comparison of AMBI, TGN and PFN for treatment of unstable trochanteric fractures. Arch Orthop Trauma Surg 2005;125:462-8. CrossRef

4. Uzun M, Ertürer E, Oztürk I, Akman S, Seçkin F, Ozçelik IB. Longterm radiographic complications following treatment of unstable intertrochanteric femoral fractures with the proximal femoral nail and effects on functional results. [Article in Turkish] Acta Orthop Traumatol Turc 2009;43:457-63. CrossRef

5. Gardenbroek TJ, Segers MJ, Simmermacher RK, Hammacher ER. The proximal femur nail antirotation: an identifiable improvement in the treatment of unstable pertrochanteric fractures? J Trauma 2011;71:16974. CrossRef

6. Pu JS, Liu L, Wang GL, Fang Y, Yang TF. Results of the proximal femoral nail anti-rotation (PFNA) in elderly Chinese patients. Int Orthop 2009;33:1441-4. CrossRef

7. Simmermacher RK, Ljungqvist J, Bail H, Hockertz T, Vochteloo AJ, Ochs $\mathrm{U}$, et al. The new proximal femoral nail antirotation (PFNA) in daily prac- tice: results of a multicentre clinical study. Injury 2008;39:932-9. CrossRef

8. Simmermacher RK, Bosch AM, Van der Werken C. The AO/ASIFproximal femoral nail (PFN): a new device for the treatment of unstable proximal femoral fractures. Injury 1999;30:327-32. CrossRef

9. Al-yassari G, Langstaff RJ, Jones JW, Al-Lami M. The AO/ASIF proximal femoral nail (PFN) for the treatment of unstable trochanteric femoral fracture. Injury 2002;33:395-9. CrossRef

10. Liu Y, Tao R, Liu F, Wang Y, Zhou Z, Cao Y, et al. Mid-term outcomes after intramedullary fixation of peritrochanteric femoral fractures using the new proximal femoral nail antirotation (PFNA). Injury 2010;41:810-7.

11. Park SY, Yang KH, Yoo JH, Yoon HK, Park HW. The treatment of reverse obliquity intertrochanteric fractures with the intramedullary hip nail. J Trauma 2008;65:852-7. CrossRef

12. Soucanye de Landevoisin E, Bertani A, Candoni P, Charpail C, Demortiere E. Proximal femoral nail antirotation (PFN-ATM) fixation of extra-capsular proximal femoral fractures in the elderly: retrospective study in 102 patients. Orthop Traumatol Surg Res 2012;98:288-95. CrossRef

13. Baumgaertner MR, Curtin SL, Lindskog DM. Intramedullary versus extramedullary fixation for the treatment of intertrochanteric hip fractures. Clin Orthop Relat Res 1998;348:87-94. CrossRef

14. Fogagnolo F, Kfuri M Jr, Paccola CA. Intramedullary fixation of pertrochanteric hip fractures with the short AO-ASIF proximal femoral nail. Arch Orthop Trauma Surg 2004;124:31-7. CrossRef

15. Baumgaertner MR, Curtin SL, Lindskog DM, Keggi JM. The value of the tip-apex distance in predicting failure of fixation of peritrochanteric fractures of the hip. J Bone Joint Surg Am 1995;77:1058-64. CrossRef

16. Kouvidis G, Sakellariou VI, Mavrogenis AF, Stavrakakis J, Kampas D, Galanakis J, et al. Dual lag screw cephalomedullary nail versus the classic sliding hip screw for the stabilization of intertrochanteric fractures. A prospective randomized study. Strategies Trauma Limb Reconstr 2012;7:155-62. CrossRef

17. Lin J. Encouraging results of treating femoral trochanteric fractures with specially designed double-screw nails. J Trauma 2007;63:86-74. CrossRef

18. Ruecker AH, Rupprecht M, Gruber M, Gebauer M, Barvencik F, Briem $\mathrm{D}$, et al. The treatment of intertrochanteric fractures: results using an intramedullary nail with integrated cephalocervical screws and linear compression. J Orthop Trauma 2009;23:22-30. CrossRef

19. Zhang S, Zhang K, Jia Y, Yu B, Feng W. InterTan nail versus Proximal Femoral Nail Antirotation-Asia in the treatment of unstable trochanteric fractures. Orthopedics 2013;36:288-94. CrossRef

20. Wang CJ, Brown CJ, Yettram AL, Procter P. Intramedullary femoral nails: one or two lag screws? A preliminary study. Med Eng Phys 2000;22:61324. CrossRef

21. Megas P, Kaisidis A, Zouboulis P, Papas M, Panagopoulos A, Lambiris E. Comparative study of the treatment of pertrochanteric fractures--trochanteric gamma nail vs, proximal femoral nail. [Article in German] Z Orthop Ihre Grenzgeb 2005;143:252-7. [Abstract] CrossRef

22. Huang Y, Zhang C, Luo Y. A comparative biomechanical study of proximal femoral nail (InterTAN) and proximal femoral nail antirotation for intertrochanteric fractures. Int Orthop 2013;37:2465-73. CrossRef

23. Ertürer RE, Sönmez MM, Sarı S, Seçkin MF, Kara A, Oztürk I. Intramedullary osteosynthesis of instable intertrochanteric femur fractures with Profin ${ }^{\circledR}$ nail in elderly patients. Acta Orthop Traumatol Turc 2012;46:107-12. CrossRef

24. Strauss EJ, Kummer FJ, Koval KJ, Egol KA. The "Z-effect" phenomenon defined: a laboratory study. J Orthop Res 2007;25:1568-73. CrossRef

25. Pires RE, Santana EO Jr, Santos LE, Giordano V, Balbachevsky D, Dos Reis FB. Failure of fixation of trochanteric femur fractures: Clinical recommendations for avoiding Z-effect and reverse Z -effect type complica- 
tions. Patient Saf Surg 2011;5:17. CrossRef

26. Werner-Tutschku W, Lajtai G, Schmiedhuber G, Lang T, Pirkl C, Orthner E. [Intra- and perioperative complications in the stabilization of perand subtrochanteric femoral fractures by means of PFN]. Unfallchirurg 2002;105:881-5. CrossRef

27. Boldin C, Seibert FJ, Fankhauser F, Peicha G, Grechenig W, Szyszkowitz $\mathrm{R}$. The proximal femoral nail (PFN)--a minimal invasive treatment of unstable proximal femoral fractures: a prospective study of 55 patients with a follow-up of 15 months. Acta Orthop Scand 2003;74:53-8. CrossRef
28. Herrera A, Domingo LJ, Calvo A, Martínez A, Cuenca J. A comparative study of trochanteric fractures treated with the Gamma nail or the proximal femoral nail. Int Orthop 2002;26:365-9. CrossRef

29. Banan H, Al-Sabti A, Jimulia T, Hart AJ. The treatment of unstable, extracapsular hip fractures with the AO/ASIF proximal femoral nail (PFN)--our first 60 cases. Injury 2002;33:401-5. CrossRef

30. Rappold GM, Hertz H, Spitaler R, Implant Breakage of the Proximal Femoral Nail(PFN).Reasons and case reports. . European Journal of Trauma 2001, p. 333-7.

\section{ORİJINAL ÇALIŞMA - ÖZET}

\section{İntertrokanterik femur kırıklarının tedavisinde iki farklı proksimal femur civisinin karşılaştırılması}

Dr. Gökçer Uzer, ${ }^{1}$ Dr. Nuh Mehmet Elmadağ, ${ }^{1}$ Dr. Fatih Yıldız, ${ }^{1}$ Dr. Kerem Bilsel, ${ }^{1}$ Dr. Tunay Erden, ${ }^{1}$ Dr. Hüseyin Toprak ${ }^{2}$

${ }^{1}$ Bezmialem Üniversitesi Tıp Fakültesi, Ortopedi ve Travmatoloji Anabilim Dalı, İstanbul

${ }^{2}$ Bezmialem Üniversitesi Tıp Fakültesi, Radyoloji Anabilim Dalı, İstanbul

AMAÇ: Kalça çivileme (PFN) yaşı hastalardaki instabil intertrokanterik femur kırıklarının (ITF) tedavisinde sıklıkla kullanılmaktadır. Bu geriye dönük çalışmada, kırık sahasında kompresyona izin veren birbirine entegre, birbirine kilitlenebilir kompresyon lag vidası kiti ya da iki ayrı lag vidası kullanılan PFN ile tedavi edilmiş olan hastaların fonksiyonel, radyolojik sonuçları ve komplikasyonları karşılaştıııldı.

GEREÇ VE YÖNTEM: Mayıs 2010 ve Nisan 2012 tarihleri arasında, AO/OTA 3I-A2 ITF kırığı için ameliyat edilmiş olan I I 8 hastadan takipleri ve kayıtları yeterli olan 82'si incelendi. Kompresyon yapabilen, birbirine kilitlenebilir, entegre lag vidası kiti olan PFN (Grup I) 44 hastada, iki ayrı lag vidası olan PFN ise (Grup II) 38 hastada kullanıldı. Sonuç parametreleri radyolojik olarak varusta çökme ve bacak boyu eşitsizliği, fonksiyonel olarak da Batı Ontario ve McMaster Üniversiteleri artrit indeksi (WOMAC) ve Harris kalça skorları (HHS) idi.

BULGULAR: Ortalama takip süresi olan 20 (I2-36) ayda tüm kırıklar iyileşti. Grup I ve Grup Il'de sırasıyla, ortalama varus çökmesi $2.03^{\circ}$ ve $5.21^{\circ}$ $(p=0,0 \mathrm{I})$, ortalama HHS 73,2 ve 74,72 ( $p=0,54)$, ortalama WOMAC skorları ise 70,78 ve $71,78(p=0,69)$ olarak bulundu. Sonuç parametreleri ve komplikasyon oranları bakımından gruplar arasında anlamlı bir fark görülmedi ( $p>0.05)$.

TARTIŞMA: İntertrokanterik femur kırıklarının tedavisinde, birbirine entegre ve birbirine kilitlenebilir kompresyon lag vidası veya iki ayrı lag vidası kullanılan PFN'ler arasında fonksiyonel, radyolojik sonuçlar ve komplikasyon oranları açısından fark bulunmamaktadır.

Anahtar sözcükler: İntertrokanterik femur kırı̆̆, kompresyon, proksimal femur çivisi.

Ulus Travma Acil Cerrahi Derg 2015;21(5):385-391 doi: 10.5505/tjtes.2015.72173 